\title{
Growth Performance Evaluation of Crossbred Male Calves of Holstein Friesian with Arsi Cattle Fed on Different Dietary Ration
}

\author{
Genet Dadi ", Ashebir Worku, Aman Gudeto, Tesfye Alemu Tucho, Mieso Guru, Frehiwot Mesele, \\ Girma Debele
}

Oromia Agriculture Research Institute (IQQO), Adami Tulu Agriculture Research Center, Batu, Ethiopia

Email address:

sosnadadi@gmail.com (G. Dadi)

${ }^{*}$ Corresponding author

To cite this article:

Genet Dadi, Ashebir Worku, Aman Gudeto, Tesfye Alemu Tucho, Mieso Guru, Frehiwot Mesele, Girma Debele. Growth Performance Evaluation of Crossbred Male Calves of Holstein Friesian with Arsi Cattle Fed on Different Dietary Ration. American Journal of Environmental and Resource Economics. Vol. 6, No. 1, 2021, pp. 11-15. doi: 10.11648/j.ajere.20210601.12

Received: December 4, 2020; Accepted: February 6, 2021; Published: March 10, 2021

\begin{abstract}
The study was done at Adami Tulu Agricultural Research Center (ATARC) to investigate the effect of different dietary ration on growth performance of crossbred male calves and to identify the most economical feeding dietary ration. Three dietary treatments rations (treatment one $=65 \%$ wheat bran $+35 \%$ Cotton seed cake, treatment two $=50 \%$ wheat bran $+49 \%$ Noug cake and treatment three $=20 \%$ Maize grain $+45 \%$ wheat bran $+35 \%$ Noug seed cakes) were evaluated. Complete Randomized Block Design was used to assign eighteen cross bred male calves randomly to three dietary rations. All experimental calves were supplemented dietary rations based on their body weight at the rate of $2.5 \%$ of their live body weight throughout the experimental period. The results indicated that there were significant difference in average daily weight gain and total weight gain between crossbred male calves fed with dietary T1 and T3. Calves fed with dietary ration T1 and T2 numerically difference in final body weight, even though not statistically significant. Partial budget analysis indicated that there was no significant difference among calves fed with three dietary feed rations. But cross bred male calves fed with dietary treatment T2 was numerically higher in gross margin as compared to T1 and T3 rations. Further evaluation of different dietary rations on growth performance of yearling age (1-1.5 years old) cross bred bull calves were warranted to attain export market live weight at early age.
\end{abstract}

Keywords: Crossbred Calves, Growth Performance, Dietary Ration

\section{Introduction}

Livestock is an important agriculture sector in livestock production systems namely crop livestock mixed, agropastoral and pastoral systems [1]. The cattle play indispensable roles as sources of meat, milk, income and foreign exchange to Ethiopian economy. Livestock sector contributes about $15 \%$ of the total export earnings and $30 \%$ of the agricultural employment. Beside the values of cattle among the farming communities and to the national economy at large, this sector has remained under-developed [2].

Ethiopian average carcass production per beef is $108.4 \mathrm{~kg}$ which less than $146 \mathrm{~kg}$ for Africa and $205 \mathrm{~kg}$ for the world [3-5]. The meat percapita consumption of meat is 13.9 $\mathrm{kg} / \mathrm{year}$ in Ethiopia averages that lower than Africa and the world percapita averages, which are 27 and $100 \mathrm{~kg} /$ year, respectively [6]. The low carcass yield might be associated with subsistence oriented livestock production system [7].

Ethiopian government sets a goal in growth transformation plan to increase meat production to meet growing meet demand [8]. The high amount of meat is commonly produced from old culled oxen, cows and other species like goats and sheep. Fattening of old animals are produced more fat which is not preferred by many consumers as compare to lean meat produced from young animals.

Consumption of lean meat produced from calves is not well known in Ethiopia even though it is very popular and well known in developed countries. The endeavors so far 
made regarding to beef cattle fattening technologies did not address fattening of crossbred male calves less than one year. Rather than slaughtering/selling of male calves at their early stages, addition of value on crossbred calves produced under dairy operation did not practice in many dairy farms. Information/technologies regarding to fattening of male calf is scant in this country. Small and large dairy farms found in urban and peri-urban areas did not practice finishing/fattening of young male calves.

The feed shortage has reached chronic level due to decreasing of grazing land which is mainly attributed to the expansion of cropland [9]. As a result of this keeping of extra male calves produced in urban and peri urban dairy production system create many challenges for dairy producers.

If calves fattening technology is generated and delivered for dairy farmers, they do not keep surplus male calves for many years. On top of this, they will increase their income by fattening of males calves at early stage before they incurred high cost of production by keeping of male calves. Addition of value on weaned male calves to optimize the output obtained from calves play a significant role on the income of dairy producers and other actors in the chain. Therefore, the study on growth performance of crossbred male calves' was designed to cover the following objectives.

1) To investigate the effect of different feeds on the growth performance of cross bred male calves

2) To identify the most economical dietary ration for fattening of crossbred male calves

\section{Methodologies}

\subsection{Study Area}

The study trail was done at Adami Tulu Agriculture Research Center that found near Batu town and $167 \mathrm{~km}$ far from Addis Ababa city. The agro ecological Zone of the area is semi-arid and sub humid with acacia woodland vegetation type. The rain fall is $760 \mathrm{~mm}$. Adami Tulu Agriculture Research Center temperature is $12.6-27^{\circ} \mathrm{C}$.

\subsection{Experimental animals}

A total of eighteen F1 cross bred male calves produced by crossing of Holstein Friesian with Arsi Cow at ATARC were selected for the experiment. The calves were injected anti parasites before the starting the trial. The vaccination was given for important diseases in the area.

\subsection{Experimental Dietary Ration}

The following three treatments were used throughout the fattening period.

$\mathrm{T} 1=$ Rhodes hay $+65 \%$ Wheat bran $+35 \%$ Cotton seed cakes

$\mathrm{T} 2=$ Rhodes hay $+50 \%$ Wheat bran $+49 \%$ Noug seed cake

$\mathrm{T} 3=$ Rhodes hay $+20 \%$ Maize grain $+45 \%$ Wheat bran + $35 \%$ Noug seed cake.

\subsection{Feeding Management}

The Rhodes hay was given freely to the experimental calves. Each calf was supplemented concentrate based on their body weight. The feed amounts that given to experimental calves were adjusted based on their body gain in fifteen day interval. The animals were fed in individually bases. The feeding trial was stopped at ninety days.

\subsection{Measurements}

The fattening calves were weighed every two weeks (fortnightly) using weighing scale and the average daily weight gain (ADG) of the fattening calves were calculated using the following formula

$$
\mathrm{ADG}=(\mathrm{FWT}-\mathrm{IWT}) / \mathrm{D}
$$

Where: FWT=Final body weight, IWT=Initial body weight, $\mathrm{D}=$ number of fattening days

\subsection{Partial Budget Analysis}

The variable costs that incurred during fattening period were recorded properly in order to analysis the financial return. The purchase price of experimental calves, feed cost, labor cost and veterinary costs were included in the partial budget analysis. The purchasing and selling prices of experimental calves were estimated by help of experienced three persons. The fixed cost was excluded from partial budget analysis. Hence, this partial budget analysis indicates only gross margin of fattening calves using the three different feed options.

\subsection{Statistical Analysis}

The weight data of the experimental calves were analyzed using general linear model (GLM) of Statistical Analysis System (SAS, 2002). The estimated least squares means were separated using the Turkey Test at $\mathrm{P}<0.05$.

\section{Results and Discussion}

\subsection{The Growth Response of Calves Fed on Dietary Ration}

The study results on daily weight gain per calf was higher $(0.67 \mathrm{~kg})$ for group of animals fed on cotton seed cake based diet (Treatment -1) followed by the group of calves fed on maize base diet $(0.56 \mathrm{~kg})$ (treatment -2$)$ than daily weight gain of calves $(0.52 \mathrm{~kg})$ that fed noug seed cake and wheat bran based diets (treatment -3 ). The results indicated that there were statistically significant variations $(\mathrm{P}<0.05)$ in average daily gain and total weight gain among the treatments. But there is no statically difference with final body weight among the treatments. However, the experimental calves fed on treatment one numerically gained higher in final body weight (149.33) than the experimental calves fed on treatment two and treatment three. 
Table 1. Body weight gain of crossbred calves fed on different dietary ration.

\begin{tabular}{llll}
\hline Parameter (kg) & T1 & T2 & T3 \\
\hline Initial body weight & $89.17 \mathrm{a} \pm 6.90 \mathrm{a}$ & $83.67 \pm 7.77 \mathrm{a}$ & $86.83 \pm 6.70 \mathrm{a}$ \\
Final body weight & $149.33 \pm 11.41 \mathrm{a}$ & $134 \pm 10.27 \mathrm{a}$ & $133.83 \pm 8.78 \mathrm{a}$ \\
$\begin{array}{l}\text { Total weight gain } \\
\text { Average daily weight } \\
\text { gain }\end{array}$ & $60.17 \pm 4.63 \mathrm{ab}$ & $50.33 \pm 2.95 \mathrm{ab}$ & $47 \pm 4.51 \mathrm{~b}$ \\
\hline
\end{tabular}

Where $\mathrm{T} 1=$ treatment one, $\mathrm{T} 2=$ Treatment two, $\mathrm{T} 3=$ Treatment three.

The daily weight gain $(0.67 \mathrm{~kg} /$ day $)$ of calves fed on Rhodes hay $+65 \%$ wheat bran $+35 \%$ cotton seed cakes was higher than with the finding of Gadzama, I. U., et al [10] who reported the daily weight gain of $0.59 \mathrm{~kg}$ /day Friesian $\mathrm{X}$ Bunaji Calves Fed $75 \%$ soymilk and $25 \%$ but lower than Cholistani calves fed on cotton seed cake based diet $(0.71 \mathrm{~kg})$ and comparable by calves fed Anmol Vanda based diet (0.69 $\mathrm{kg)}[11]$.

\subsection{Trend of Body Growth}

The daily weight gain trend of experimental calves fed on three different feeds ration over the whole 90 fattening day is indicated in Figure 1. The weight change of crossbred male calves of six to nine month were increased as number of the fattening period. Live weight gain of animal is influenced by different factors such as physiological condition, utilization of nutrient, environment and management of the animal. Animals fed forages and concentrates achieved higher growth rate at different stages of growth [12]. Accordingly, other finding indicated that the growth of cattle is linear increased [13] with a certain stage of age and was positively related with the initial live weight of the animal. Yanar and Aydin [14] reported that daily live weight gain at 6-9 months, 9- 12 months, 12-15 months and 15-18 months was 452.0, $325.0,325.0$ and $224.0 \mathrm{~g} / \mathrm{d}$, respectively, which showed higher growth.

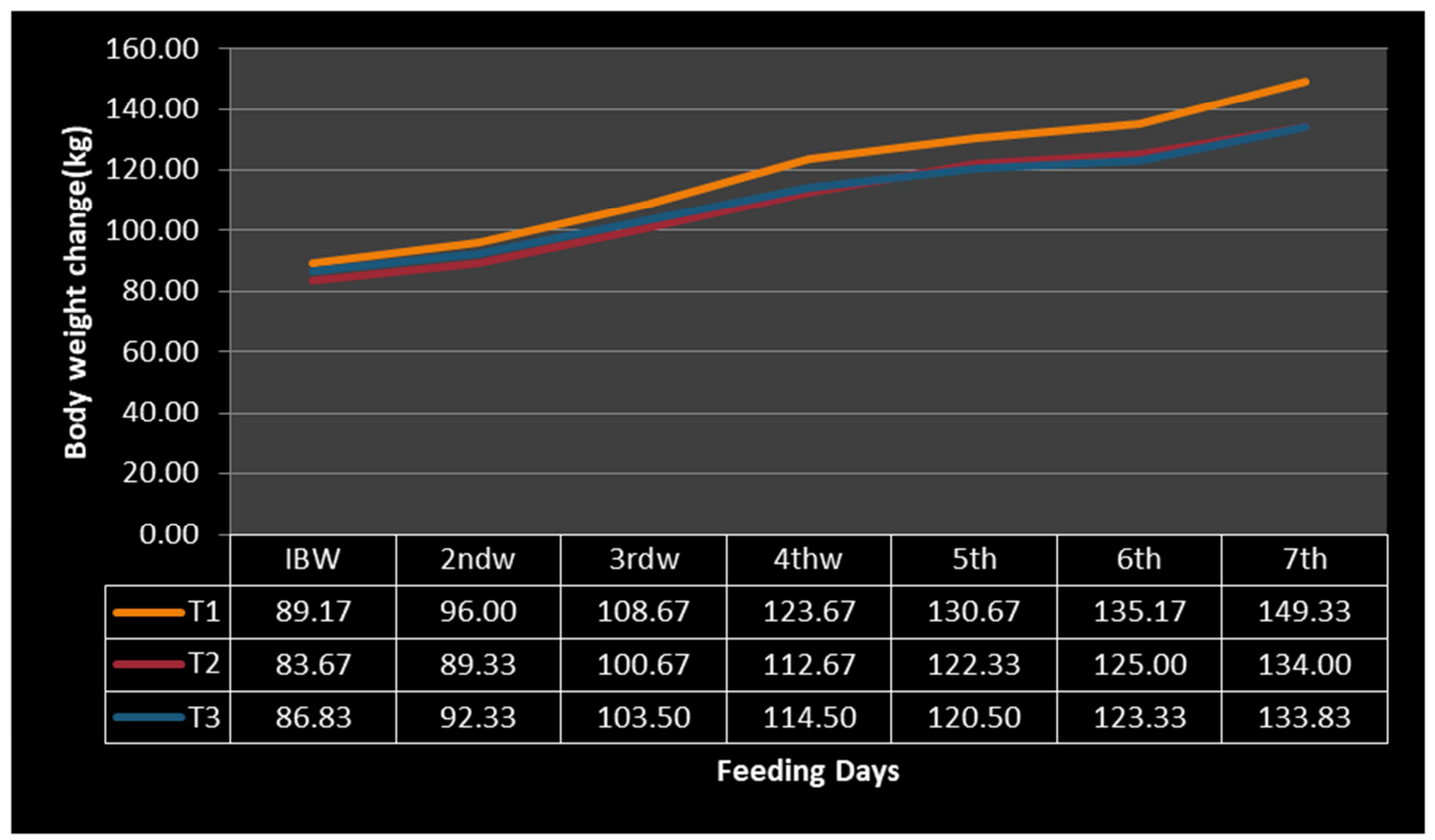

Where: D14=day 14 , D28=day 28, etc up to D105=day 105 th

Figure 1. Body weight change of six to nine month F1 cross bred male calves over the total fattening period.

\subsection{Feed Intakes and Daily Weight Gain}

The average daily feeds intake and daily weight gain of experimental calves from the beginning of the fattening trial to the end of the fattening periods is depicted in Table 2 below.

Table 2. Daily feed intake and daily weight gain of crossbred male calves.

\begin{tabular}{|c|c|c|c|c|c|c|c|c|c|}
\hline Days & T1 & & & T2 & & & T3 & & \\
\hline & FI (kg) & DWG (kg) & FCR & FI (kg) & DWG (kg) & FCR & FI (kg) & DWG (kg) & FCR \\
\hline $0-15 d$ & 2.36 & 0.46 & 5.13 & 2.19 & 0.37 & 5.92 & 2.31 & 0.36 & 6.42 \\
\hline $15-30 \mathrm{~d}$ & 2.55 & 0.84 & 3.04 & 2.46 & 0.76 & 3.24 & 2.61 & 0.74 & 3.53 \\
\hline $30-45 \mathrm{~d}$ & 2.57 & 1.00 & 2.57 & 2.28 & 0.80 & 2.85 & 2.43 & 0.74 & 3.28 \\
\hline $45-60 d$ & 3.29 & 0.47 & 7.00 & 2.96 & 0.64 & 4.63 & 2.99 & 0.40 & 7.48 \\
\hline $60-75 d$ & 3.01 & 0.30 & 10.00 & 2.84 & 0.18 & 15.78 & 2.78 & 0.19 & 14.63 \\
\hline $75-90 d$ & 3.45 & 0.94 & 3.67 & 3.15 & 0.60 & 5.25 & 3.16 & 0.70 & 4.51 \\
\hline
\end{tabular}

$\mathrm{FI}=$ feed intake, $\mathrm{DWG}=$ daily weight gain, $\mathrm{FCR}=$ feed conversion ratio 
As it is indicated in the (Table 2), the experimental animals feed intake increases as the body weight advanced through feeding days. The rate of daily weight gain of experimental calves was steadily increased up to the end of the fattening periods which similar to the finding of Girma et al. [17]. The daily dry matter intake was increased as experimental animals grown.

\subsection{Partial Budget Analysis}

Feedlot profit margin is a function of animal purchasing and selling prices, feed costs and utilization efficiency, and the time spent in the feedlot $[15,16]$. Partial budget analysis indicated that there was no significant difference among calves fed with three dietary feed rations. But cross bred male calves fed with dietary treatment two was numerically higher in gross margin as compared to cross bred calves fed with dietary treatment one and treatment three. This is due to relatively lower feed cost in cross bred male calves with treatment two as compared to the feed cost of calves fed treatment and treatment three.

Table 3. Distribution of average cost and return per treatment of calves.

\begin{tabular}{llll}
\hline Variable (ETB) & Treatment one & $\begin{array}{l}\text { Treatment } \\
\text { two }\end{array}$ & $\begin{array}{l}\text { Treatment } \\
\text { three }\end{array}$ \\
\hline Calves price & 9900 & 9800 & 9600 \\
Drug & 20 & 30 & 20 \\
Labor & 2100 & 2100 & 2100 \\
Feeds & 11668.8 & 11216.12 & 11471.79 \\
TVC & 23688.8 & 23146.12 & 23191.79 \\
Gross revenue & 29700 & 29400 & 28800 \\
GM (GR - TVC) & 6011.2 & 6253.88 & 5608.21 \\
Unit profit & 1001.87 & 1042.31 & 934.70 \\
\hline
\end{tabular}

$\mathrm{GM}=$ gross margin, $\mathrm{GR}=\mathrm{Gross}$ revenue, $\mathrm{TVC}=$ Total variable cost, $\mathrm{ETB}=$ Ethiopian Birr

\section{Conclusion and Recommendation}

The results indicated that there was significant variation in daily weight gain and total weight gain between cross bred calves fed with dietary ration treatment one and treatment three. Calves fed with dietary ration treatment one and treatment two numerically difference in final body weight, even though it was not statistically significant. Partial budget analysis revealed that there was no variation among calves fed with three dietary feed rations. But crossbred male calves fed with dietary treatment two was numerically higher in gross margin as compared to crossbred calves fed with dietary treatment one and treatment three rations. Therefore, young calves can be fed on one of the three dietary feed options based on the availability and accessibility of the feeds in the area. Further evaluation of different dietary feed rations on growth performance of yearling age (1-1.5 years old) of cross bred bull calves is warranted to attain export market live weight at their early age.

\section{References}

[1] Ayeneshet B, Abera M, Wondifraw Z. (2018). Reproductive and Productive Performance of Indigenous Dairy Cows under Smallholder Farmers Management System in North. Journal of Fisheries \& Livestock Production. 6 (1): 1-5.

[2] Gebretnsae Mezgebe, Solomon Gizaw, Mengistu Urge, Arvind Chavhan (2017). Begait cattle production systems and production performances in northern Ethiopia. Int. J. of Life Sciences. 5 (4): 506-516.

[3] Negassa, A., Shahidur, R., Gebremedhin, B. (2011). Livestock Production and Marketing in Ethiopia. Ethiopia Strategy Support Program II, ESSP II Working Paper, pp: 26-35.

[4] Yesihak Y. M., Webb E. C. (2015). Causes of Beef Carcass and Organ Condemnations in Ethiopia. Asian Journal of Animal and Veterinary Advances, 10 (4), 147-160.

[5] Zekarias Bassa, Shewan Gizawu Wolde, Tesfaye Alemu, Melese Yilma, Asrat Terra, Berekt Zeleke, Deibe Gemiyu (2016). Evaluation of Locally Available Energy Source Feeds on Fattening Performance of Local Oxen and Carcass Analysis in Wolaita, Southern Ethiopia. Hydrol Current Res 7: 255. doi: $10.4172 / 2157-7587.1000255$.

[6] Tsigereda Fekadu, Mengistu Urge, Emebet Moreda (2016). Assessment of Traditional Cattle Fattening Practices in Hararghe Highland Parts of Ethiopia. World journal of agricultural science, 2016, 12 (2): 149-160. ISSN 1817-3047.

[7] Tsegay Teklebrhan, Mengistu Urge (2013). Assessment of commercial feedlot finishing practices at eastern Shoa, Ethiopia. Open Journal of Animal Sciences, Vol. 3, No. 4, 273-280.

[8] Aman Gudeto, Tesfaye Alemu T. Ashebir Worku, Frehiwot Mesele, Genet Dadi, Mieso Guru (2020). On-farm evaluation and demonstration of different feeding Agricultural Science. Volume 2 issue 1.

[9] Mekuria, W., Mekonnen, K., Thorne, P. et al. Competition for land resources: driving forces and consequences in croplivestock production systems of the Ethiopian highlands. Ecol Process 7, 30 (2018). https://doi.org/10.1186/s13717-0180143-7.

[10] Gadzma, I. U., Yashim, S. M., Abdu, S. B., Makun, H. J., Barje, P. P., Achi, N. P. (2018). Feed, Intake, growth performance and Nutrient Utilization in Friesian xBunaji calves Fed Soya milk based Milk replacer. J. Animal Prod. Res. (2017) 29 (2): 96-111.

[11] Iftikhar Ali1, Umar Farooq, Sajid Hameed', Faisal Shehzad", Falik Sher Khan, Muhammad Asim Tausif (2008). Performance of Cholistani Male Cattle Calves Fed Fattening Ration Under Local Climatic Conditions. Pak. J. Agri. Sci., Vol. 45 (2).

[12] Khan M. R. (2003). Royal of agro based industry for national economic development. P. 18 Proc. Semin. Role. Agro. Based. Indust. Nat. Econ. Dev. Dhaka, Bangladesh.

[13] Haque F. M., Paul D. C., Mahabbatullah M. (2005). Farming systems research activities on livestock component at Bangladesh Agricultural Research Institute. Pp. 182-194 in Proc. Livest. Dev. Bangladesh. Savar, Dhaka, Bangladesh. 
[14] Aydin, R., Yanar, M., Kocyigit, R., Diler, A., Ozkilicci, T. Z., 2009. Effect of direct-fed microbials plus enzyme supplementation on the fattening performance of Holstein young bulls at two different initial body weights. African Journal of Agricultural Research., Vol. 4. P. 548-552.

[15] Malope P, Tsopito. CM, Aganga AA, Madibela OR, (2007). Profitablity of dry season beef -lotting in rain deficit countries: the cae of Botswana. Livestock Res. Rular Dev., 19 (6).

[16] Mlote, SN, Mdoe, NSY, Isinika, A. C, Mtenga, L. A (2012).
Value addition of beef cattle fattening in the Lake Zone in Tanzania: Challenges and opportunities. Livestock Res. Rural Dev., 24 (95).

[17] Girma D, Mieso G, Tesfaye A, Arse G, Frehowit M, Ashebir W and Aman G. (2015). Effect of different feeds option on growth response and carcass characteristic of two years aged Borana bulls for export market weight gain at Adami Tulu Agricultural Research Center. Basic Research Journal of Agricultural Science Vol. 4 (5) pp. 139-145. 